Once you have Acrobat Reader open on your computer, click on the Comment tab at the right of the toolbar:

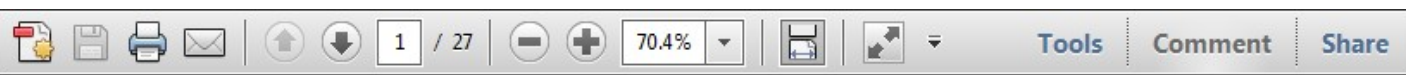

This will open up a panel down the right side of the document. The majority of tools you will use for annotating your proof will be in the Annotations section, pictured opposite. We've picked out some of these tools below:

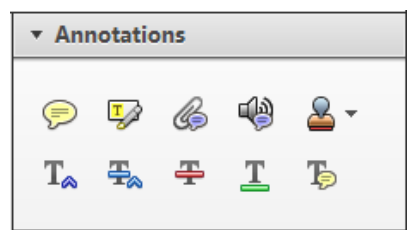

\section{Replace (Ins) Tool - for replacing text.}

Trikes a line through text and opens up a text box where replacement text can be entered.

\section{How to use it}

- Highlight a word or sentence.

- Click on the Replace (Ins) icon in the Annotations section.

- Type the replacement text into the blue box that appears.

ıdard tramework for the analysis of $\mathrm{m}$ icy-Nevertheless, it also led to exog،

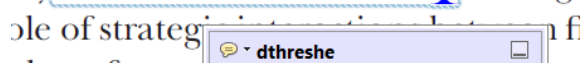
aber of comp 08/06/2011 15:58:17 $\quad$ O

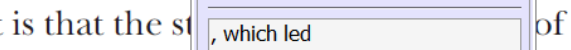
nain compo: be level, are exc nc

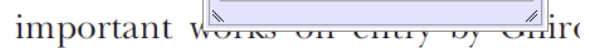
M henreforth) ${ }^{1}$ we onen the 'hlarl t

3. Add note to text Tool - for highlighting a section to be changed to bold or italic.

T. Highlights text in yellow and opens up a text box where comments can be entered.

\section{How to use it}

- Highlight the relevant section of text.

- Click on the Add note to text icon in the Annotations section.

- Type instruction on what should be changed regarding the text into the yellow box that appears.

namic responses of mark ups ent with the VAR evidence

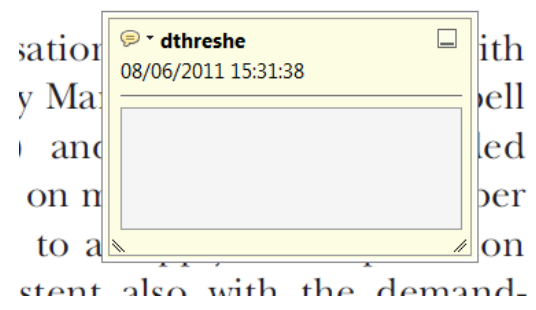

\section{Strikethrough (Del) Tool - for deleting text.}

T. Strikes a red line through text that is to be deleted.

How to use it

- Highlight a word or sentence.

- Click on the Strikethrough (Del) icon in the Annotations section.

there is no room for extra protits al s ups are zero and the number of zet) values are not determined by Blanchard and Kiyotaki (1987), sfect competition in general equilil ts of aggregate demand and supply lassical framework assuming monol ean an evorensuc numher of firme

\section{Add sticky note Tool - for making notes at} specific points in the text.

\section{Marks a point in the proof where a comment} needs to be highlighted.

How to use it

- Click on the Add sticky note icon in the Annotations section.

- Click at the point in the proof where the comment should be inserted.

- Type the comment into the yellow box that appears.

iailu ailu suppiy siluks. Hivsl vi

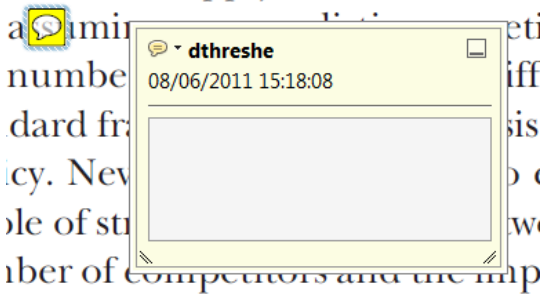

lber of "

is that the structure of the sects 
5. Attach File Tool - for inserting large amounts of text or replacement figures.

Inserts an icon linking to the attached file in the appropriate place in the text.

\section{How to use it}

- Click on the Attach File icon in the Annotations section.

- Click on the proof to where you'd like the attached file to be linked.

- Select the file to be attached from your computer or network.

- Select the colour and type of icon that will appear in the proof. Click OK.

E N D

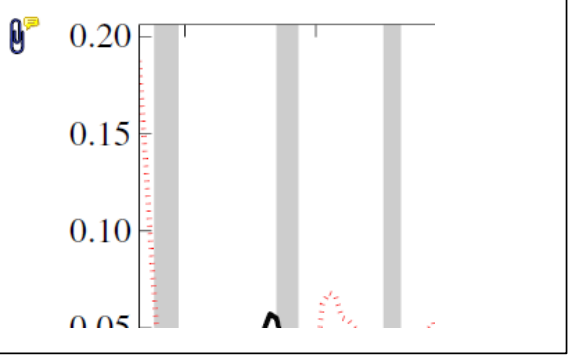

6. Drawing Markups Tools - for drawing shapes, lines and freeform annotations on proofs and commenting on these marks.

Allows shapes, lines and freeform annotations to be drawn on proofs and for comment to be made on these marks.

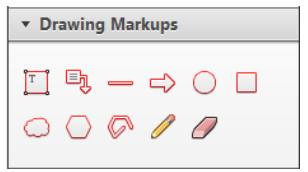

How to use it

- Click on one of the shapes in the Drawing Markups section.

- Click on the proof at the relevant point and draw the selected shape with the cursor.

- To add a comment to the drawn shape, move the cursor over the shape until an arrowhead appears.

- Double click on the shape and type any text in the red box that appears.

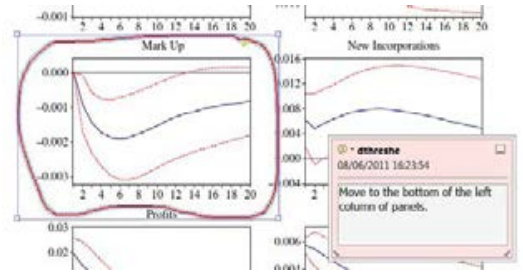




\title{
Quantitative approach for the early detection of selection for virulence of Meloidogyne incognita on resistant tomato in 2 I plastic greenhouses
}

\author{
3 A. Giné and F. J. Sorribas* \\ Departament d'Enginyeria Agroalimentària i Biotecnologia, Universitat Politècnica de Catalunya, Esteve Terradas 8, 08860 Castelldefels, \\ Barcelona, Spain
}

Resistant tomato cultivars are an important tool to control Meloidogyne spp., which cause the highest yield losses attributed to plant-parasitic nematodes. However, the repeated cultivation of $M i$ resistant cultivars can select virulent populations. In the present study, the susceptible tomato cv. Durinta and the resistant cv. Monika were cultivated from March to July in a plastic greenhouse for 3 years to determine the maximum multiplication rate, maximum nematode density, equilibrium density, relative susceptibility and population growth rate of $M$. incognita; these were used as proxy indicators of virulence and yield losses. The values of population dynamics and growth rate on the resistant tomato increased year by year and were higher when it was repeatedly cultivated in the same plot compared to when it was alternated with the susceptible cultivar and the level of resistance decreased from very to moderately resistant. The relationship between the nematode density at transplanting $\left(P_{\mathrm{i}}\right)$ and the relative yield of tomato fitted to the Seinhorst damage model for susceptible, but not resistant, cultivars. The tolerance limit and the relative minimum yield were 2-4 J2 per $250 \mathrm{~cm}^{3}$ of soil and $0.44-0.48$, respectively. The tomato yield did not differ between cultivars at low $P_{\mathrm{i}}$, but it did at higher $P_{\mathrm{i}}$ values, at which the resistant yielded $50 \%$ more than the susceptible. This study demonstrates the utility of population dynamics parameters for the early detection of selection for virulence in Meloidogyne spp., and that three consecutive years were not sufficient to select for a completely virulent population.

Keywords: damage function, equilibrium density, maximum multiplication rate, root-knot nematodes, Solanum tycopersich, virulence selection

\section{Introduction}

Tomato (Solanum lycopersicum) is one of the most important crops in Europe, being cultivated mostly in the Mediterranean region where about two-thirds of the production comes from Italy and Spain (EUROSTAT, 2008). In Spain the annual production exceeds 4 million tonnes in $48617 \mathrm{ha}$, of which $38.05 \%$ is conducted under plastic houses (MAGRAMA, 2013), mainly as a monocrop (Talavera et al., 2012).

Root-knot nematodes (RKN), Meloidogyne spp., are mainly responsible for yield losses caused by plant-parasitic nematodes on horticultural crops, primarily under protected cultivation (Sikora \& Fernández, 2005). In Spain, under protected cultivation, the maximum vegetable yield losses due to $M$. incognita and/or M. javan$i c a$, the most frequent RKN species in vegetable growing areas, reached $88 \%$ on cucumber, $60 \%$ on tomato and $39 \%$ on courgette (Sorribas et al., 2005; Talavera et al., 2009; Giné et al., 2014; Vela et al., 2014). Among all available control methods to manage RKN, plant resistance is the principal control method to be used in

*E-mail: francesc.xavier.sorribas@upc.edu integrated nematode management strategies, due to its cost-effectiveness, its compatibility with other control methods and its nil environmental impact (Starr et al., 2002). Resistant plants are able to suppress the development and reproduction of plant-parasitic nematodes (Roberts, 2002). In tomato, resistance is conferred by the Mi-1.2 gene introgressed from Solanum peruvianum (Smith, 1944), which is active against M. arenaria, M. incognita and M. javanica (Williamson, 1998). Nevertheless, plant resistance to these nematode species conferred by the $M i-1.2$ gene is compromised when soil temperatures are sustained above $28^{\circ} \mathrm{C}$ (Dropkin, 1969), and/or against $M i$-virulent populations or other RKN species such as M. hapla, M. chitwoodi race 3 (Brown et al., 1997), M. enterolobi (Kiewnick et al., 2009) or M. exigua (Silva et al., 2008). Moreover, the genetic background of the resistant tomato plant has also been shown to have an impact on the effectiveness of the Mi-1.2- mediated resistance to the targeted RKN species (Cortada et al., 2008). Despite this, resistant tomato cultivars and/or rootstocks are widely used, and the repeated cultivation of resistant genotypes can select for $M i$-virulent RKN-populations that can overcome the protective effect conferred by the Mi-1.2 gene (Williamson, 1998; Verdejo-Lucas et al., 2009). The selection of $M i$ - 
virulent nematode populations can be detected by an increase of population density at the end of the resistant crop $\left(P_{\mathrm{f}}\right)$, which tends to be similar to that achieved on a susceptible cultivar for a given density at transplanting $\left(P_{\mathrm{i}}\right)$. That is, when the maximum multiplication rate ( $a$, defined as the multiplication rate in absence of limiting factors), the maximum $P_{\mathrm{f}}$ achieved by a nematode population on a plant host under particular conditions $(M)$, and the equilibrium density $\left(E, P_{\mathrm{i}}\right.$ at which the plant can supply enough food to maintain the population density at end of the crop; $P_{\mathrm{f}}=P_{\mathrm{i}} ; P_{\mathrm{f}} / P_{\mathrm{i}}=1$; Seinhorst, 1967), on the resistant genotype are close to those on the susceptible cultivar. Another useful indicator of virulence selection is the population's growth rate (the relationship between the multiplication rate $\left(P_{\mathrm{f}} / P_{\mathrm{i}}\right)$ and $\left.P_{\mathrm{i}}\right)$. This parameter allows the comparison of the nematode population dynamics on different plant species or genotypes of the same plant species, the efficacy of control methods, or between cropping seasons for a given pathosystem (Talavera et al., 2009; Vela et al., 2014). All these relationships provide an insight into nematode reproduction, but do not provide information on the plants' tolerance, which can be assessed by establishing the relationship between the $P_{\mathrm{i}}$ and crop yield, as defined by the Seinhorst damage function model (Seinhorst, 1965). This relationship will estimate the tolerance limit $(T)$ and the minimum relative crop yield $(m)$ for any given agronomic conditions (Seinhorst, 1965).

Testing for virulence is usually done in pot experiments at constant soil temperatures under $28^{\circ} \mathrm{C}$, using the field nematode population as inoculum and comparing its reproduction on a resistant cultivar to that on a susceptible cultivar (Sorribas et al., 2005; Verdejo-Lucas et al., 2009). This type of experiment has to be carried out at the end of the field crop, but the progressive selection of a virulent population can be detected earlier using population dynamic parameters. In this study, the maximum multiplication rate, the maximum $P_{\mathrm{f}}$, the equilibrium density, and the population growth rate of M. incognita on resistant and susceptible tomato cultivars were determined during 3 years in which resistant and/or susceptible tomato plants were cultivated in spring-summer. In addition, the effect of increasing $P_{\mathrm{i}}$ on relative crop yield of resistant and susceptible tomato cultivars was assessed under plastic greenhouse conditions.

\section{Materials and methods}

Experiments were carried out over three growing seasons (2010, 2011 and 2012) in a $700 \mathrm{~m}^{2}$ plastic greenhouse located in Viladecans (Barcelona, Spain). The soil texture was sandy loam with $83.8 \%$ sand, $6.7 \%$ loam and $9.5 \%$ clay; $\mathrm{pH} 8.7 ; 1.8 \%$ of organic matter $(\mathrm{w} / \mathrm{w})$ and $0.5 \mathrm{dS} \mathrm{m}^{-1}$ electrical conductivity. The majority of plots were infested with M. incognita in 2007. The RKN species was identified by the morphology of perineal pattern, esterase pattern, and sequence characterized amplified region (SCAR) markers (Zijlstra et al., 2000). The rest of plots remained uninfested for comparative yield studies. From 2007 to the beginning of the experiments, susceptible tomato cultivars, cucumber or black fallow succeeded in rotation, with or without the application of non-fumigant nematicides, to achieve gradients of nematode densities.

Sixty plots of $9.6 \mathrm{~m}^{2}$ were cultivated in total. Individual main plots comprised four planting rows, with six plants per row. In each plot, there was $50 \mathrm{~cm}$ between rows and plants were spaced $55 \mathrm{~cm}$ apart within rows. The distance between individual plots was $110 \mathrm{~cm}$ in between rows and $100 \mathrm{~cm}$ along rows. The sampling plots, of $3.2 \mathrm{~m}^{2}$, were composed of the two central rows of each plot, from which 8 plants were processed to conduct soil, root and yield analysis. The soil sample from each plot was prepared individually to prevent cross contamination.

Tomato plants were cultivated from 12 April to 15 July (95 days) in 2010, from 31 March to 6 July in 2011 (98 days) and from 5 March to 17 July (135 days) in 2012. Tomato crops were followed by black fallow or cucumber crop to achieve a gradient of nematode densities. In all three cropping seasons, 30 plots were cultivated with the resistant tomato cv. Monika (Syngenta Seeds) and 30 plots with the susceptible cv. Durinta (Seminis). Each tomato cultivar was grown in the same plot (i.e. cultivated consecutively) in spring-summer, or alternated with the other cultivar. Plants were irrigated by drip irrigation system as needed, and fertilized with a solution consisting of NPK $(15-5-30)$ at $31 \mathrm{~kg} \mathrm{ha}^{-1}$ and iron chelate and micronutrients at $0.9 \mathrm{~kg} \mathrm{ha}^{-1}$. Plants were vertically trained, and weeding was done manually. Fruits were harvested when reaching their standard commercial size. The accumulated tomato yield was expressed as $\mathrm{kg}$ of fruit per plant. Soil temperatures were recorded daily at 30-min intervals with digital temperature soil probes (Campbell Scientific) placed at $15 \mathrm{~cm}$ depth.

Nematode population densities were determined at transplanting $\left(P_{\mathrm{i}}\right)$ and at the end $\left(P_{\mathrm{f}}\right)$ of each crop. Samples consisted of eight cores taken from the first $30 \mathrm{~cm}$ of soil with a $2.5 \mathrm{~cm}$ diameter auger. Soil samples were mixed and passed through a 4-mm-pore sieve to remove stones and roots. For each experimental plot, mobile juveniles (J2) were extracted from $500 \mathrm{~cm}^{3}$ of soil composite samples using modified Baermann trays (Whitehead \& Hemming, 1965) incubated at $27^{\circ} \mathrm{C}$ for 1 week. The J2 present in the soil were then collected using a $25 \mu \mathrm{m}$ aperture screen. The roots retained in the $4 \mathrm{~mm}$ sieve were rinsed with tap water, weighed and chopped, and eggs were extracted by blender maceration in a $1 \% \mathrm{NaOCl}$ solution for 10 min (Hussey \& Barker, 1973). Initial population density $\left(P_{\mathrm{i}}\right)$ was expressed as $\mathrm{J} 2$ per $250 \mathrm{~cm}^{3}$ of soil because no roots were found. Final population density $\left(P_{\mathrm{f}}\right)$ included both number of $\mathrm{J} 2$ extracted from $500 \mathrm{~cm}^{3}$ of soil and number of eggs extracted from roots contained in this volume of soil and was expressed as $\mathrm{J} 2+$ eggs per $250 \mathrm{~cm}^{3}$. The nematode multiplication rate was calculated as $P_{\mathrm{f}} / P_{\mathrm{i}}$.

At the end of the cropping season, plants were removed from the ground with a pitchfork. Disease severity, expressed as the gall index (GI), was rated, using Zeck's range, from 0 to 10 (Zeck, 1971), where $0=$ complete and healthy root system and $10=$ plants and roots dead. Roots were rinsed with tap water, weighed and chopped in 1-cm-long segments; two $20 \mathrm{~g}$ subsamples were used to extract eggs as described above (Hussey \& Barker, 1973). Root infestation by the nematode was expressed as number of eggs per gram of fresh root weight. To determine the resistance level of the tomato cultivars assessed, the reproduction index (RI) was calculated as the percentage of eggs per gram of root on the resistant tomato cultivar compared to the reproduction on the susceptible one. The RI value allows the categorization of the response of the resistant cultivar as highly resistant 
$(\mathrm{RI}<1 \%)$, very resistant $(1 \% \leq \mathrm{RI}<10 \%)$, moderately resistant $(10 \% \leq \mathrm{RI}<25 \%)$, slightly resistant $(25 \% \leq \mathrm{RI}<50 \%)$ or susceptible (RI $\geq 50 \%$ ) (Hadisoeganda \& Sasser, 1982).

The maximum multiplication rate $(a)$ was estimated by the slope of the linear regression between $P_{\mathrm{f}}$ and the lowest values of $P_{\mathrm{i}}$, according to $P_{\mathrm{f}}=a P_{\mathrm{i}}$ (Seinhorst, 1970). The maximum population density at the end of the crop $(M)$ was determined from the experimental data, and the equilibrium density $(E)$ was calculated according to the equation $M=a E /(a-1)$ (Schomaker \& Been, 2006). The relative susceptibility was calculated as the ratio of $a$ or $M$ between the resistant and the susceptible tomato cultivars (Schomaker \& Been, 2006).

\section{Statistical analysis}

Data were analysed using SAS v. 9. Values of $P_{\mathrm{i}}$ and $P_{\mathrm{f}} / P_{\mathrm{i}}$ were transformed to $\log _{10}(x)$ to linearize, and submitted to regression analysis (PROC REG) for each tomato cultivar and year for determination of the population growth rate. The contrast of the linear regressions between years for each tomato cultivar was conducted using the general lineal model procedure (PROC GLM). In addition, contrasts between the relationship between $P_{\mathrm{i}}$ and $P_{\mathrm{f}} / P_{\mathrm{i}}$ from plots in which resistant $(\mathrm{R})$ or susceptible $(\mathrm{S})$ tomato were cropped one (i.e. for the resistant cultivar the underlined letter of the following combinations were used: RSS, RSR, RRS, RRR, SRR, SRS, SSR), two (i.e. for the resistant cultivar the underlined letter of the following combinations were used: RRS, RRR, SRR) or three consecutive years (i.e. for the resistant cultivar the underlined letter of the combination RRR was used) were carried out to determine the putative selection for virulence according to its population growth rate. Both the GI and the number of eggs per gram of root measured on both the resistant and the susceptible tomato cultivars were compared for each cropping season and between years of repeated cultivation, by analysis of variance. Means were separated by the least significant difference (LSD) $(P<0.05)$.

Annual tomato yield was compared between cultivars for each $P_{\mathrm{i}}$ range, using the Student's $t$-test. The $P_{\mathrm{i}}$ ranges were $0,1-10$, $11-100,101-300,301-500$ and $501-1448 \mathrm{~J} 2$ per $250 \mathrm{~cm}^{3}$ of soil in 2010 and $0,10-100,101-300,301-500,501-1000$ and $1001-3322 \mathrm{~J} 2$ per $250 \mathrm{~cm}^{3}$ of soil in 2012. Data on tomato yield for 2011 could not be included for comparison because plants suffered blossom abortion, irrespective of the cultivar. In addition, the relative yield of each tomato cultivar and the $P_{\mathrm{i}}$ values were submitted to a nonlinear regression analysis using the nonlinear procedure (PROC NLIN) in order to determine their compliance with the Seinhorst damage function model $\left(y=m+(1-m) 0.95^{(P i / T-1)}\right)$, where $m$ is the minimum relative yield and $T$ is the nematode population density above which yield losses begin to occur. The values of $m$ and $T$ used to start the iteration were estimated by plotting the experimental values of tomato yield against $\log _{10}\left(P_{\mathrm{i}}\right)$. Contrasts with the Seinhorst damage function model were done considering confidence intervals at $95 \%$ of $m$ and $T$.

\section{Results}

Mean soil temperatures ranged from 17.2 to $30.9^{\circ} \mathrm{C}$ (mean $26.0^{\circ} \mathrm{C}$ ) in 2010 , from 19.7 to $31.4{ }^{\circ} \mathrm{C}$ (mean $25.4^{\circ} \mathrm{C}$ ) in 2011 , and from 17.0 to $31.5^{\circ} \mathrm{C}$ (mean $24.5^{\circ} \mathrm{C}$ ) in 2012 . The number of days with mean soil temperatures above $28{ }^{\circ} \mathrm{C}$ during tomato crops was 18 , 22 and 27 in 2010, 2011 and 2012, respectively. Absolute minimum and maximum soil temperatures during the period in which mean soil temperatures were above $28^{\circ} \mathrm{C}$ were 25.7 and $34.9{ }^{\circ} \mathrm{C}$. Fluctuations of mean soil temperatures during the 3 years of study are presented in Figure 1.

The nematode population was able to complete two generations during each cropping season according to the accumulated soil temperatures $\left(1521,1504\right.$ and $1959{ }^{\circ} \mathrm{C}$ DD degree days over a base temperature $\left(T_{\mathrm{b}}\right)$ of $10^{\circ} \mathrm{C}$ in 2010, 2011 and 2012, respectively) and its thermal requirements on tomato (thermal constant $(S)=600-700$ DD over $T_{\mathrm{b}}=10^{\circ} \mathrm{C}$, Ferris et al., 1985).

Nematode population densities at the beginning of tomato crops ranged from 0 to $1448 \mathrm{~J} 2$ per $250 \mathrm{~cm}^{3}$ of soil in 2010 , from 0 to $3749 \mathrm{~J} 2$ per $250 \mathrm{~cm}^{3}$ of soil in 2011, and from 0 to $3322 \mathrm{~J} 2$ per $250 \mathrm{~cm}^{3}$ of soil in 2012. The maximum multiplication rate, maximum population density, and equilibrium density of M. incognita on both susceptible and resistant tomato cultivars each year and during three consecutive years are shown in
Figure 1 Fluctuation of mean daily soil temperatures in the plastic greenhouse located in Viladecans (Spain) infested by Meloidogyne incognita and cultivated with susceptible tomato cv. Durinta and resistant tomato cv. Monika. Soil temperatures were taken at $15 \mathrm{~cm}$ depth. The cropping period is indicated by the shaded areas.

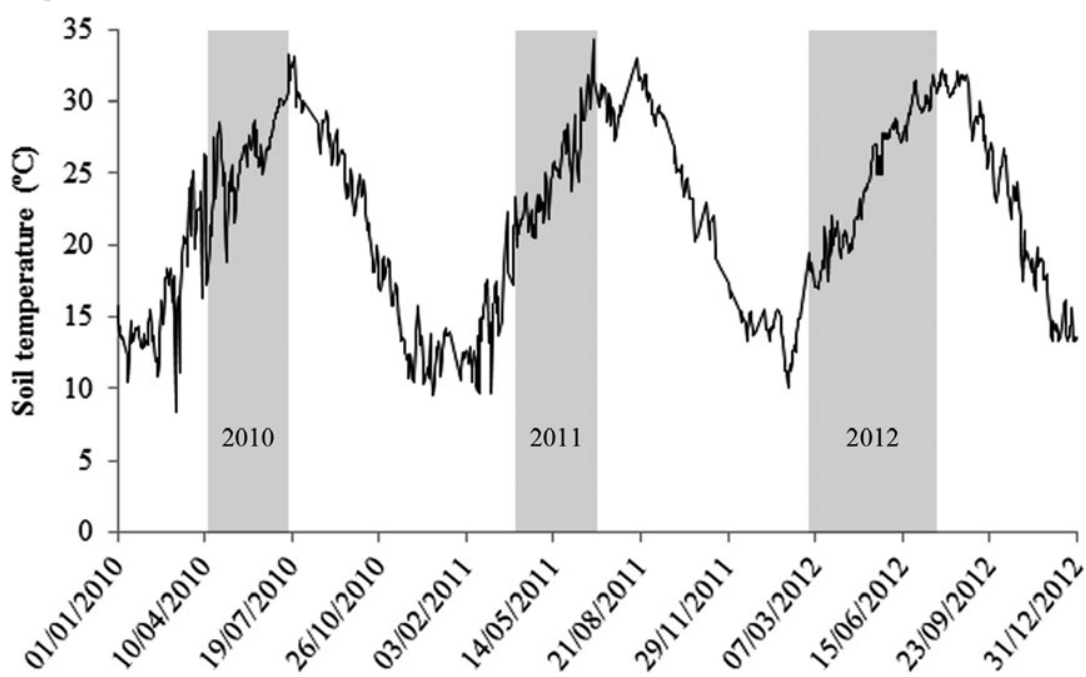

Plant Pathology (2017) 
Table 1 Maximum multiplication rate (a), maximum population density ( $M, J 2+$ eggs per $250 \mathrm{~cm}^{3}$ soil) and equilibrium density ( $E$, J2+ eggs per $250 \mathrm{~cm}^{3}$ soil) of Meloidogyne incognita on resistant tomato cv. Monika and susceptible tomato cv. Durinta after each year of cultivation (2010, 2011 and 2012) and after 1, 2 or 3 consecutive years of cultivation

\begin{tabular}{|c|c|c|c|c|c|c|c|c|c|}
\hline & \multicolumn{3}{|c|}{ Susceptible } & \multicolumn{3}{|c|}{ Resistant } & \multicolumn{3}{|c|}{ Resistant:susceptible (\%) } \\
\hline & $\bar{a}$ & $M$ & $E$ & $\bar{a}$ & $M$ & E & $a$ & M & $E$ \\
\hline 2010 & 9774 & 12956 & 12955 & 105 & 2254 & 2233 & 1.07 & 17.40 & 17.23 \\
\hline 2011 & 8819 & 15173 & 15171 & 400 & 17477 & 1748 & 4.54 & 11.55 & 11.52 \\
\hline 2012 & 8205 & 14086 & 14004 & 654 & 4176 & 4170 & 7.97 & 29.65 & 29.77 \\
\hline After 1 year $^{a}$ & 9659 & 13444 & 13422 & 270 & 2255 & 2247 & 2.80 & 16.77 & 16.74 \\
\hline After 2 years & 8819 & 16846 & 16845 & 350 & 4897 & 4880 & 3.96 & 29.1 & 28.97 \\
\hline After 3 years & 8457 & 19959 & 19957 & 1932 & 5275 & 5272 & 22.84 & 26.43 & 26.42 \\
\hline
\end{tabular}

${ }^{\mathrm{a}}$ For 1 year, data from 53 plots for each tomato cultivar in which only one resistant or susceptible tomato were cultivated or the first resistant or susceptible tomato crop if more than one was cultivated (i.e. for the resistant cultivar the underlined letter of the following combinations were used: RSS, RSR, RRS, RRR, SRR, SRSS, SSR). For 2 consecutive years, 23 plots for each tomato cultivar (i.e. for the resistant cultivar the underlined letter of the following combinations were used: RRS, RRR, SRR). For 3 consecutive years, eight plots were used for each tomato cultivar (i.e. for the resistant cultivar the underlined letter of the combination $\underline{R R R}$ was used).

Table 1. The relative susceptibility of the resistant tomato cv. Monika increased during both repeated and alternated cultivation; however, after the third year of repeated cultivation, the $a$ value was still only $25 \%$ that of the susceptible cultivar (Table 1).

The relationship between $P_{\mathrm{i}}$ and $P_{\mathrm{f}} / P_{\mathrm{i}}$ on the susceptible tomato did not differ among the three growing seasons (intercept $P=0.3175$; slope $P=0.7034$ ) and data was pooled to obtain a general regression. On the resistant tomato, the relationship between $P_{\mathrm{i}}$ and $P_{\mathrm{f}} / P_{\mathrm{i}}$ differed among the cropping seasons (intercept $P<0.0001$; slope $P=0.7558$ ) as well as from that of the susceptible cultivar (Fig. 2a). During the three planting seasons, the GI and the number of eggs per gram of root on the resistant tomato ranged from 14.1 to $30.7 \%$, and from 3.6 to $9.4 \%$, respectively, of those on the susceptible tomato. Cultivar Monika remained very resistant $(\mathrm{RI}<10 \%)$ over the three cropping seasons (Table 2 ).

After the repeated cultivation of the susceptible cultivar, again, the relationship between $P_{\mathrm{i}}$ and $P_{\mathrm{f}} / P_{\mathrm{i}}$ did not
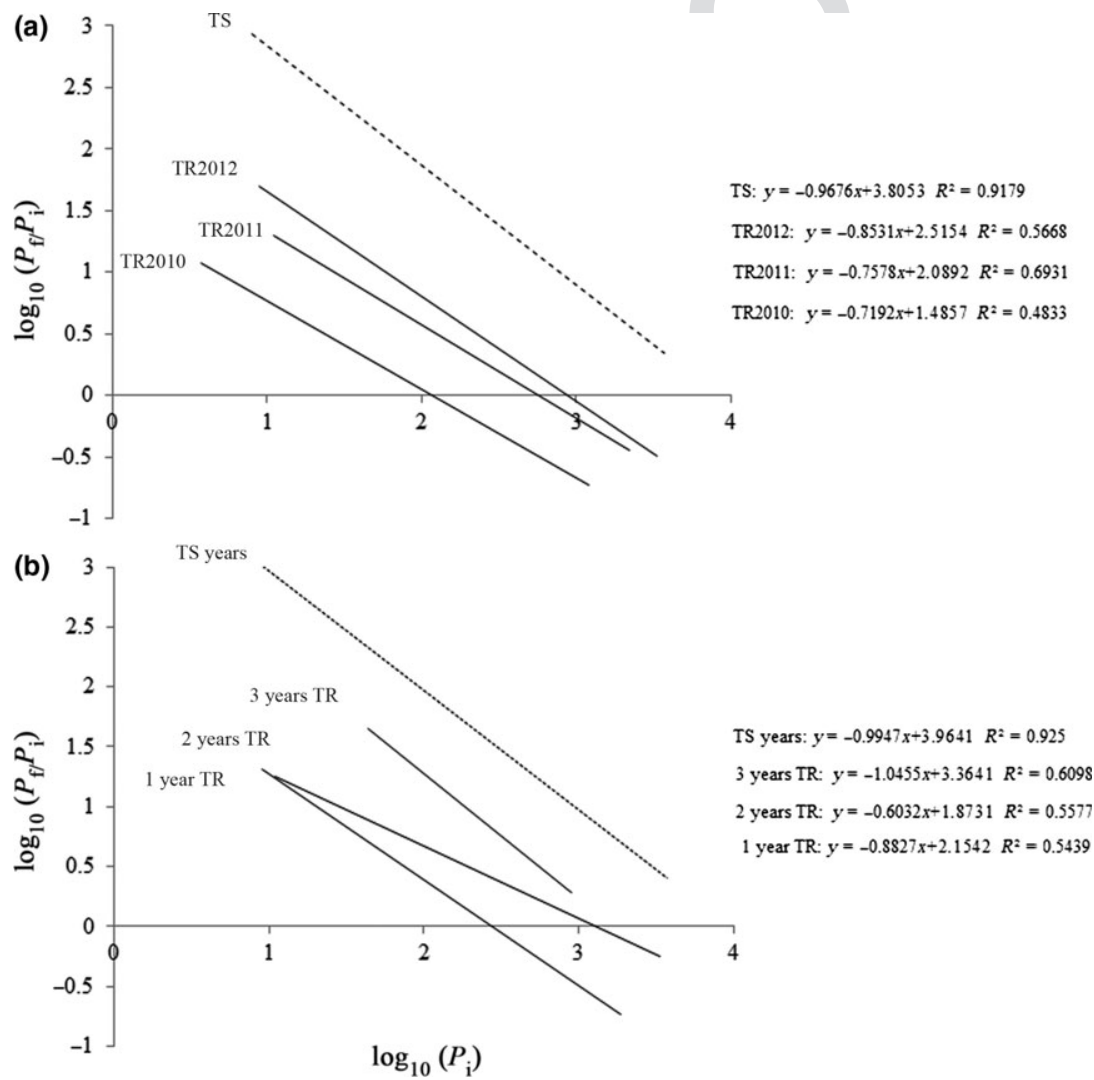

Figure 2 The relationship between initial population density $\left(P_{\mathrm{i}}, \mathrm{J} 2\right.$ per $250 \mathrm{~cm}^{3}$ of soil) and the multiplication rate (final population density/initial population density, $P_{\mathrm{f}}\left(P_{\mathrm{i}}\right)$ of Meloidogyne incognita over three cropping seasons (a) and over 1, 2 or 3 consecutive years of cultivation (b) of the susceptible tomato cv. Durinta (TS and TS years) and the resistant cv. Monika (TR2010, TR2011 and TR2012, and 1 year TR, 2 years TR and 3 years TR) in a plastic greenhouse in Viladecans (Spain). 
Table 2 Galling index (GI), eggs per gram of root and reproduction index (RI) of Meloidogyne incognita, on tomato cv. Durinta (susceptible) and tomato cv. Monika (resistant) in 2010, 2011 and 2012 and in repeated cultivation (after 1, 2 and 3 years) in a plastic greenhouse in Viladecans (Spain)

\begin{tabular}{|c|c|c|c|c|c|c|}
\hline & \multicolumn{2}{|l|}{$\mathrm{Gl}^{\mathrm{a}}$} & \multicolumn{2}{|c|}{ Eggs per gram of root } & \multirow[b]{2}{*}{$\mathrm{Rl}^{\mathrm{b}}$} & \multirow[b]{2}{*}{ Category } \\
\hline & Susceptible & Resistant & Susceptible & Resistant & & \\
\hline 2010 & $6.5 \pm 0.4 b$ & $1.3 \pm 0.1 b$ & $5147 \pm 546 b$ & $183 \pm 90 b$ & 3.1 & VR \\
\hline 2011 & $7.1 \pm 0.3 \mathrm{ab}$ & $1.0 \pm 0.1 b$ & $7228 \pm 251 \mathrm{ab}$ & $378 \pm 62 b$ & 5.2 & VR \\
\hline 2012 & $7.5 \pm 0.3 a$ & $2.3 \pm 0.1 \mathrm{a}$ & $8329 \pm 832 \mathrm{a}$ & $780 \pm 143 a$ & 9.4 & VR \\
\hline After 1 year $^{\mathrm{c}}$ & $7.0 \pm 0.3 a$ & $1.2 \pm 0.1 b$ & $6637 \pm 395 b$ & $261 \pm 57 b$ & 3.9 & VR \\
\hline After 2 years & $7.0 \pm 0.2 \mathrm{a}$ & $1.5 \pm 0.2 b$ & $7392 \pm 390 a b$ & $632 \pm 136 b$ & 8.5 & VR \\
\hline After 3 years & $6.8 \pm 0.3 a$ & $2.4 \pm 0.4 a$ & $9574 \pm 2220 a$ & $969 \pm 264 a$ & 10.1 & MR \\
\hline
\end{tabular}

Data are mean \pm standard error. Data within the same column followed by the same letter did not differ $(P<0.05)$ between 2010,2011 and 2012 and in repeated cultivation according to the LSD test.

${ }^{\mathrm{a}} \mathrm{Gl}$ (galling index) on a scale from 0 to 10, where $0=$ complete and healthy root system and $10=$ plants and roots dead (Zeck, 1971).

${ }^{\mathrm{b}} \mathrm{RI}$ (reproduction index) calculated as the number of eggs per gram of root on the resistant $\mathrm{cv}$. Monika and divided by the number of eggs per gram of root on the susceptible cv. Durinta $\times 100$. Categories: VR: very resistant $(\mathrm{RI}<10 \%)$, MR: moderately resistant $(10 \% \leq \mathrm{RI}<25 \%)($ Hadisoeganda \& Sasser, 1982).

${ }^{\mathrm{C}}$ For 1 year, data from 53 plots for each tomato cultivar in which only one resistant or susceptible tomato were cultivated or the first resistant or susceptible tomato crop if more than one was cultivated (i.e. for the resistant cultivar the underlined letter of the following combinations were used: $\underline{R S S}, \underline{R S R}, \underline{R R S}, \underline{R R R}, \mathrm{SRR}, \underline{\mathrm{SRS}}, \mathrm{SS} \underline{\mathrm{R}}$ ). For 2 consecutive years, 23 plots for each tomato cultivar (i.e. for the resistant cultivar the underlined letter of the following combinations were used: RRS, RRR, SRR). For 3 consecutive years, eight plots were used for each tomato cultivar (i.e. for the resistant cultivar the underlined letter of the combination $\underline{\operatorname{RRR}}$ was used).

Table 3 Yield $\left(\mathrm{kg} \mathrm{plant}^{-1}\right)$ of resistant tomato cv. Monika and susceptible tomato cv. Durinta in soil infested by Meloidogyne incognita in a plastic greenhouse in Viladecans (Spain) in 2010 and 2012 with increasing initial population $\left(P_{i}\right)$ range

\begin{tabular}{ccll}
\hline & & \multicolumn{2}{l}{ Yield $\left(\mathrm{kg} \mathrm{plant}{ }^{-1}\right)$} \\
\cline { 3 - 4 } Year & $P_{\mathrm{i}}$ range & Monika & Durinta \\
\hline 2010 & 0 & $2.3 \pm 0.4$ & $2.6 \pm 0.3$ \\
& $1-10$ & $1.9 \pm 0.04$ & $1.8 \pm 0.2$ \\
& $11-100$ & $2.1 \pm 0.3$ & $1.7 \pm 0.2$ \\
& $101-300$ & $2.3 \pm 0.2$ & $1.1 \pm 0.1^{*}$ \\
& $301-500$ & $1.9 \pm 0.1$ & $1.2 \pm 0.1^{*}$ \\
& $501-1448$ & $2.2 \pm 0.2$ & $1.3 \pm 0.2^{*}$ \\
& $0-10$ & $2.0 \pm 0.5$ & $1.3 \pm 0.4$ \\
& $11-100$ & $2.2 \pm 0.2$ & $0.9 \pm 0.1^{*}$ \\
& $101-300$ & $2.2 \pm 0.3$ & $0.9 \pm 0.2^{*}$ \\
& $301-500$ & $2.2 \pm 0.2$ & $0.5 \pm 0.1^{*}$ \\
& $501-1000$ & $2.3 \pm 0.2$ & $0.5 \pm 0.02^{*}$ \\
& $1001-3322$ & $2.5 \pm 0.3$ & $0.5 \pm 0.3^{*}$ \\
\hline
\end{tabular}

Values are means \pm standard deviations per each $P_{\mathrm{i}}$ range. Data within the same row with * are significantly different according to Student's t-test $(P<0.05)$.

differ, and data was pooled to obtain a general regression (intercept $P=0.9006$; slope $P=0.8515$ ); however, the relationship between $P_{\mathrm{i}}$ and $P_{\mathrm{f}} / P_{\mathrm{i}}$ did differ on the resistant tomato (intercept $P=0.0327$; slope $P=0.0295)$ and also between the two tomato cultivars (Fig. 2b). The GI and the number of eggs per gram of root obtained on the resistant tomato after 1, 2 and 3 years of repeated cultivation were 17.1, 21.4, and $35.3 \%$, respectively and, on the susceptible cultivar Durinta, were $3.9,8.6$ and $10.1 \%$, respectively (Table 2 ). Both GI and the number of eggs per gram of root
Table 4 Parameters of the Seinhorst damage function model for tomato cv. Durinta cropped in soil infested by Meloidogyne incognita in a plastic greenhouse in Viladecans (Spain) in 2010 and 2012

\begin{tabular}{lllll}
\hline Year & $m$ & $T\left(\mathrm{~J} 2\right.$ per $250 \mathrm{~cm}^{3}$ of soil $)$ & $R^{2}$ & $P$ \\
\hline 2010 & $0.48 \pm 0.09$ & $2.02 \pm 0.98$ & 0.94 & $<0.001$ \\
2012 & $0.44 \pm 0.18$ & $4.43 \pm 4.26$ & 0.82 & $<0.001$ \\
\hline
\end{tabular}

Data are mean \pm confidence interval (95\%). Seinhorst damage function model: $y=m+(1-m) 0.95^{(P i / T-1)}$, where $m$ is the minimum relative yield, $P_{\mathrm{i}}$ is the initial population density and $T$ is the tolerance limit.

obtained after 3 years of cultivation were higher $(P<0.05)$ than those obtained during the first and the second year. After 3 years of repeated cultivation of the resistant tomato, the level of resistance decreased from very to moderately resistant (Table 2 ).

Tomato yield differed between cultivars when $P_{\mathrm{i}}$ was higher than $100 \mathrm{~J} 2$ per $250 \mathrm{~cm}^{3}$ of soil in 2010 and when $P_{\mathrm{i}}$ was higher than $10 \mathrm{~J} 2$ per $250 \mathrm{~cm}^{3}$ of soil in 2012 (Table 3). At the highest $P_{\mathrm{i}}$, the resistant cv. Monika yielded 41 and $80 \%$ more $(P<0.05)$ than the susceptible cv. Durinta in 2010 and 2012, respectively.

The relationship between $P_{\mathrm{i}}$ and the relative yield fitted to the Seinhorst damage model in 2010 and 2012 (Table 4) on the susceptible tomato cultivar, but not for the resistant $\mathrm{cv}$. Monika. The tolerance limit $(T)$ and the relative minimum yield $(m)$ in 2010 were $2 \mathrm{~J} 2$ per $250 \mathrm{~cm}^{3}$ of soil and 0.48 , respectively, and, in 2012, were $4 \mathrm{~J} 2$ per $250 \mathrm{~cm}^{3}$ of soil and 0.44 , respectively.

\section{Discussion}

This study demonstrates, for the first time, the utility of population dynamic parameters for the early detection of 
selection for virulence of RKN, and confirms that three successive crops of the resistant cv. Monika were not sufficient for selection of a completely virulent population, as previously stated (Sorribas et al., 2005; Verdejo-Lucas et al., 2009).

The results of the present study confirm the efficacy of Mi-1.2-mediated resistance to supress M. incognita reproduction and disease severity without significant yield losses compared to susceptible tomato cultivars (Rich \& Olson, 2004; Sorribas et al., 2005). However, the resistant tomato cultivar did not confer immunity against $M$. incognita because a proportion of the nematode population was able to infect, develop and reproduce on it. Thus, a low proportion of the nematodes within the studied population were able to overcome the resistance provided by the $M i-1.2$ gene when they was exposed for the first time to the resistant tomato cultivar. The percentage of $\mathrm{J} 2$ that was able to reproduce on the $M i$ resistant tomato cv. Monika increased over the years, after repeated cultivation, but without achieving an entirely $M i$-virulent population $(\mathrm{RI}>50 \%)$. In this study, population dynamic parameters $(a, M$ and $E)$ were used to assess the selection of $M i$-virulent populations. Over the experimental period, the $a, M$, and $E$ values on the resistant cultivar increased to $25 \%$ of the values on the susceptible cultivar, indicating that selection for virulence was taking place. Evidence of selection for $M i$ virulence was also given by the population growth rate (relationship between $P_{\mathrm{f}} / P_{\mathrm{i}}$ and $P_{\mathrm{i}}$ ), which was higher when the resistant tomato was repeatedly cultivated in the same plot than when it was alternated with the susceptible cultivar, as previously found by Talavera et al. (2009). Thus, the maximum multiplication rate and the equilibrium density increased from 1.5 to $25.1 \%$ and from 2.9 to $17.1 \%$ of the values obtained on the susceptible cultivar, respectively. GI and eggs per gram of root also increased after repeated cultivation of the resistant tomato ( 2 and 3.7 times, respectively), but did not reach the values observed on the susceptible cultivar, which were 2.8 and 9.9 times higher, respectively.

The tomato cv. Monika was very resistant to M. incognita when it was alternated with the susceptible cultivar, but was only moderately resistant $(\mathrm{RI}=10.1)$ the third year after repeated cultivation in the same plots. This indicates that selection for $M i$-virulence was occurring, although the research period was not sufficient to obtain a fully virulent population. Some reports have shown an increase in the reproduction index of M. incognita after 3 years of repeated cultivation of the resistant cv. Monika in a plastic greenhouse; the cultivar was found to be only slightly (RI $=26)$, rather than moderately resistant (Sorribas et al., 2005), or susceptible $(\mathrm{RI}=108)$, rather than slightly resistant (Verdejo-Lucas et al., 2009) to the nematode population by the end of these studies, indicating that selection for $M i$-virulence was underway. Some RKN populations can be naturally $M i$-virulent without previous exposure to an $M i$-resistant cultivar (Ornat et al., 2001), can be selected (Williamson, 1998), or can be achieved progressively after repeated cultivation of resistant genotypes (Eddaoudi et al., 1997). The values resulting from the population dynamics, as well as those coming from the population growth rates, could be helpful for the early detection of such selection for virulence.

In the present study, sustained daily mean soil temperatures above $28{ }^{\circ} \mathrm{C}$ were only achieved at the end of the crop, but the temperature fluctuated over each day. It has been demonstrated that tomato resistance under intermittent elevated soil temperatures above $28{ }^{\circ} \mathrm{C}$ did not compromise the resistance (Verdejo-Lucas et al., 2013). In fact, a minimum of $48-72 \mathrm{~h}$ at constant temperatures of $32{ }^{\circ} \mathrm{C}$ were needed for breaking tomato resistance (Dropkin, 1969), conditions that did not occur in the present study. Thus, it was not considered that high soil temperatures in the study caused failure of the Mi-1.2 gene.

The tolerance limit of both tomato cultivars did not differ, but the resistant cultivar yielded about $50 \%$ more than the susceptible in both cropping seasons, confirming previous results observed in the Mediterranean agroecologic conditions (Sorribas et al., 2005; Talavera et al., 2009).

Including plant resistance in rotation sequences can be a useful tool to prevent the build up of RKN densities and to reduce yield losses in the following susceptible crop, as has been previously reported (Rich \& Olson, 2004; Talavera et al., 2009). Nonetheless, when the selection for $M i$-virulence begins, both virulent and avirulent subpopulations coexist in the same agricultural soil and, as the present results showed, the selected Mi-virulent subpopulation is maintained, regardless of the following susceptible crop. However the fitness associated with the acquisition of this $\mathrm{Mi}$ virulent status by the nematode population is unclear. In some cases, it has been associated with a reduction of infective capacity and/or fecundity on susceptible genotypes or other susceptible plant hosts (DjianCaporalino et al., 2011). Other reports do not identify any adverse cost of fitness (Tzortzakakis et al., 1998) and others indicate both adverse and no effect, depending on the virulent nematode lines (Petrillo \& Roberts, 2005). For this reason, the only way to maintain the efficacy of the Mi-1.2 resistance gene in tomato cultivars (S. lycopersicum $\times$ S. peruvianum) in the long term is to prevent an increase in the frequency of $M i$-virulent individuals over the nonvirulent within the population. As the virulence is highly specific to a given resistance gene, rotation with crops containing other single resistance genes and non-host crops could promote the durability of the resistance conferred by the Mi-1.2 resistance gene (Djian-Caporalino et al., 2011).

\section{Acknowledgements}

This research was funded by Spanish National Institute for Agriculture and Food Research and technology (INIA) project RTA 2010-00017-C02 and the European 
Fund for Economic and Regional Development (FEDER). The authors acknowledge Marta Almazan, Maria Julià, Sheila Alcalá, Cristian Gómez and Miquel Massip for field and laboratory support.

\section{References}

Brown CR, Mojtahedi H, Santo GS, Willamson VM, 1997. Effect of the Mi gene in tomato on reproductive factors of Meloidogyne chitwoodi and M. hapla. Journal of Nematology 29, 416-9.

Cortada L, Sorribas FJ, Ornat C, Kaloshian I, Verdejo-Lucas S, 2008. Variability in infection and reproduction of Meloidogyne javanica on tomato rootstocks with the Mi resistance gene. Plant Pathology 57, $1125-35$.

Djian-Caporalino C, Molinari S, Palloix A et al., 2011. The reproductive potential of the root-knot nematode Meloidogyne incognita is affected by selection for virulence against major resistance genes from tomato and pepper. European Journal of Plant Pathology 131, 431-40.

Dropkin VH, 1969. The necrotic reaction of tomatoes and other hosts resistant to Meloidogyne: reversal by temperature. Phytopathology 59, $1632-7$.

Eddaoudi M, Ammati M, Rammah A, 1997. Identification of resistance breaking populations of Meloidogyne on tomatoes in Morocco and their effect on new sources of resistance. Fundamental and Applied Nematology 20, 285-9.

EUROSTAT, 2008. Agricultural Statics: Main results 2006-2007. FAOSTAT 2012 - Food and agriculture organization of the United Nations statistics. [http://faostat.fao.org]. Accessed 20 July 2016.

Ferris H, Roberts PA, Thomason IJ, 1985. Nematodes. In: Flint ML, ed. Integrated Pest Management for Tomatoes. Davis, California, USA: Integrated Pest Management, University of California: Publication $3274,60-5$.

Giné A, López-Gómez M, Vela MD et al., 2014. Thermal requirements and population dynamics of root-knot nematodes on cucumber and yield losses under protected cultivation. Plant Pathology 63, 1446-53.

Hadisoeganda WW, Sasser JN, 1982. Resistance of tomato, bean, southern pea, and garden pea cultivars to root-knot nematodes based on host suitability. Plant Disease 66, 145-50.

Hussey R, Barker K, 1973. Comparison of methods of collecting inocula of Meloidogyne spp., including a new technique. Plant Disease Reporter 57, 1025-8.

Kiewnick S, Dessimoz M, Franck L, 2009. Effects of the Mi-1 and N root-knot nematode-resistance gene on infection and reproduction of Meloidogyne enterolobii on tomato and pepper cultivars. Journal of Nematology 41, 134-9.

MAGRAMA, 2013. Ministerio de Agricultura, Alimentación y Medio Ambiente, Anuario de estadística. Superficies y producciones de cultivos. [http://www.mapama.gob.es/estadistica/pags/anuario/2013/ AE_2013_13_06_27_03.pdf]. Accessed 24 January 2017.

Ornat C, Verdejo-Lucas S, Sorribas FJ, 2001. A population of Meloidogyne javanica in Spain virulent to the Mi resistance gene in tomato. Plant Disease 85, 271-6.

Petrillo MD, Roberts PA, 2005. Fitness of virulent Meloidogyne incognita isolates on susceptible and resistant cowpea. Journal of Nematology 37, 457-66.

Rich JR, Olson SM, 2004. Influence of Mi-gene resistance and soil fumigant application in first crop tomato on root-galling and yield in a succeeding cantaloupe crop. Nematropica 34, 103-8.

Roberts PA, 2002. Concepts and consequences of resistance. In: Starr JL, Cook R, Bridge J, eds. Plant Resistance to Parasitic Nematodes. Wallingford, UK: CAB International, 23-41.
Schomaker CH, Been TH, 2006. Plant growth and population dynamics. In: Perry RN, Moens M, eds. Plant Nematology. Wallingford, UK: CAB International, 275-301.

Seinhorst JW, 1965. The relation between nematode density and damage to plants. Nematologica 11, 137-54.

Seinhorst JW, 1967. The relationship between population increase and population density in plant parasitic nematodes. III. Definition of terms host, host status and resistance. IV. The influence of external conditions on the regulation of population density. Nematologica 13, $429-42$.

Seinhorst JW, 1970. Dynamics of population of plant parasitic nematodes. Annual Review of Phytopathology 8, 131-56.

Sikora R, Fernández E, 2005. Nematode parasites of vegetables. In: Luc M, Sikora RA, Bridge J, eds. Plant Parasitic Nematodes in Subtropical and Tropical Agriculture. Wallingford, UK: CAB International, 319-92.

Silva RV, Oliviera RDL, Ferreira PS, Castro DB, 2008. Efeito do gene $M i$ na reprodução de populações de Meloidogyne exigua em tomateiro. Nematologia Brasileira 32, 150-3.

Smith PG, 1944. Embryo culture of a tomato species hybrid. Proceedings of the American Society of Horticultural Sciences 44, 413-6.

Sorribas FJ, Ornat C, Verdejo-Lucas S, Galeano M, Valero J, 2005. Effectiveness and profitability of the $M i$-resistant tomatoes to control root-knot nematodes. European Journal of Plant Pathology 111, 29-38.

Starr JL, Bridge J, Cook R, 2002. Resistance to plant parasitic nematodes: history, current use future potential. In: Starr JL, Cook R, Bridge J, eds. Plant Resistance to Parasitic Nematodes. Wallingford, UK: CAB International, 1-22.

Talavera M, Verdejo-Lucas S, Ornat C et al., 2009. Crop rotations with $M i$ gene resistant and susceptible tomato cultivars for management of root-knot nematodes in plastic-houses. Crop Protection 28, 662-7.

Talavera M, Sayadi S, Chirosa-Rios M, Salmeron T, Flor-Peregrin E, Verdejo-Lucas S, 2012. Perception of the impact of root-knot nematode-induced diseases in horticultural protected crops of southeastern Spain. Nematology 14, 517-27.

Tzortzakakis EA, Trudgill DL, Phillips MS, 1998. Evidence for a dosage effect of the $M i$ gene on partially virulent isolates of Meloidogyne javanica. Journal of Nematology 30, 76-80.

Vela MD, Giné A, López-Gómez M et al., 2014. Thermal time requirements of root-knot nematodes on zucchini-squash and population dynamics with associated yield losses on spring and autumn cropping cycles. European Journal of Plant Pathology 140, 481-90.

Verdejo-Lucas S, Cortada L, Sorribas FJ, Ornat C, 2009. Selection of virulent populations of Meloidogyne javanica by repeated cultivation of $M i$ resistance gene tomato rootstocks under field conditions. Plant Pathology 58, 990-8.

Verdejo-Lucas S, Blanco M, Cortada L, Sorribas FJ, 2013. Resistance of tomato rootstocks to Meloidogyne arenaria and Meloidogyne javanica under intermittent elevated soil temperatures above $28^{\circ} \mathrm{C}$. Crop Protection 46, 57-62.

Whitehead AG, Hemming JR, 1965. A comparison of some quantitative methods of extracting small vermiform nematodes from soil. Annual of Applied Biology 55, 25-38.

Williamson VM, 1998. Root-knot nematode resistance genes in tomato and their potential for future use. Annual Review of Phytopathology 36, 277-93.

Zeck W, 1971. Rating scheme for field evaluation of root-knot nematode infestations. Pflanzenschutz-Nachrichten Bayer 24, 141-4.

Zijlstra C, Donkers-Venne DT, Fargette M, 2000. Identification of Meloidogyne incognita, M. javanica and M. arenaria using sequence characterised amplified region (SCAR) based PCR assays. Nematology $2,847-53$. 


\section{Author Query Form}

\section{Journal: $\quad$ PPA}

Article: $\quad 12679$

Dear Author,

During the copy-editing of your paper, the following queries arose. Please respond to these by marking up your proofs with the necessary changes/additions. Please write your answers on the query sheet if there is insufficient space on the page proofs. Please write clearly and follow the conventions shown on the attached corrections sheet. If returning the proof by fax do not write too close to the paper's edge. Please remember that illegible mark-ups may delay publication.

Many thanks for your assistance.

\begin{tabular}{|l|l|l|}
\hline Query reference & Query & Remarks \\
\hline 1 & $\begin{array}{l}\text { AUTHOR: Please read through the entire proof carefully, paying particular } \\
\text { attention to the accuracy of equations, tables, illustrations (which may have been } \\
\text { redrawn), other numerical matter and references (which have been corrected for } \\
\text { style but not checked for accuracy, which remains the responsibility of the } \\
\text { author). }\end{array}$ & $\begin{array}{l}\text { AUTHOR: Please note that the version of your paper that appears online is } \\
\text { complete and final, except for volume, issue and page numbers, which are added } \\
\text { upon print publication. Therefore, there will be no further opportunity to make } \\
\text { changes to your article after online publication. }\end{array}$ \\
\hline 2 & $\begin{array}{l}\text { AUTHOR: Please confirm that given names (red) and surnames/family names } \\
\text { (green) have been identified correctly. }\end{array}$ & \\
\hline 3 & $\begin{array}{l}\text { AUTHOR: Figure 1 is of poor quality. Please check required artwork } \\
\text { specifications at http://authorservices.wiley.com/bauthor/illustration.asp }\end{array}$ & $\begin{array}{l}\text { AUTHOR: Figure 2 is of poor quality. Please check required artwork } \\
\text { specifications at http://authorservices.wiley.com/bauthor/illustration.asp }\end{array}$ \\
\hline 5 &
\end{tabular}

